ARTICLE

Received 9 Jan 2017 | Accepted 19 Jun 2017 | Published 1 Aug 2017

DOl: $10.1057 /$ palcomms.2017.70

OPEN

\title{
State and green crimes related to water pollution and ecological disorganization: water pollution from publicly owned treatment works (POTW) facilities across US states
}

\author{
Michael J. Lynch', Paul B. Stretesky ${ }^{2}$ and Michael A. Long ${ }^{2}$
}

\begin{abstract}
Green criminologists often refer to water pollution as an example of a green crime, but have yet to produce much research on this subject. The current article addresses the need for green criminological analyses of water pollution problems, and draws attention to an overlooked issue: water pollution emissions from state owned public water treatment facilities or POTWs. Legally, POTWs may emit certain quantities and kinds of pollutants to waterways following treatment. This does not mean, however, that those emissions have no adverse ecological or public health impacts, or that those emissions cannot also be employed as examples of green crimes or green-state crimes. Indeed, from the perspective of environmental sociology and ecological Marxism, those emissions generate ecological disorganization. Moreover, POTW emissions contain numerous pollutants that generate different forms of ecological disorganization. The current study uses POTW emissions data drawn from the US EPA's Discharge Monitoring Report system for 2014 to illustrate the extent of pollution emitted by POTWs in and across US states as one dimension of ecological disorganization. To contextualize the meaning of those data, we review US water pollution regulations, review the health and ecological impacts of chemicals emitted by POTWs, and situate those emissions within green criminological discussions of green crime and greenstate crimes.
\end{abstract}

\footnotetext{
${ }^{1}$ Department of Criminology, University of South Florida, Tampa, FL, USA ${ }^{2}$ Department of Social Sciences \& Languages, Northumbria University, Newcastle upon Tyne, UK
} 
G reen criminologists have long referred to water pollution as a general example of a green crime (South, 1998). Despite those references, green criminologists have devoted little attention to the study of water pollution and its consequences (for example, Lynch and Stretesky, 2013; McClanahan, 2014; Johnson et al., 2015), leaving this area of research open for further analysis of the scope, consequences, regulation and punishment of water pollution crimes. This small literature leaves much to be explored such as: the scope of water pollution problems in different contexts; the analysis of water pollution violations and the enforcement of water pollution/ quality regulations; the consequences of water pollution on ecosystem stability and waterway species; and studies exploring the intersection of water pollution and environmental justice.

Other disciplines have paid significantly more attention to detailing the extent and control of water pollution problems. By the early 1990s, agricultural engineers had already employed geographic information system software to analyse the effects of nonpoint sources of pollution on water quality (Tim et al., 1992). Environmental scientists have used complex residual variable models to estimate violations of water quality standards (Borsuk et al., 2002). Agricultural economists have modelled factors that affect the punishment of water pollution violators (Oljaca et al., 1998) and water pollution permit compliance (Bandyopadhyay and Horowitz, 2006). Given this literature outside of green criminology, it is rather surprising that green criminologists have not paid greater attention to exploring water pollution related harms as examples of green crime and injustice. Here, we draw attention to this issue by examining how water pollution from state owned/contracted publicly owned treatment work (POTWs) contributes to ecological disorganization, and the kinds of ecosystem damage those emissions produce.

POTW water pollution has not been widely described even in literatures outside of criminology. There are nearly 16,000 POTWs in the United States of America (USA), which serve about 234 million people, or $75 \%$ of the US population. POTWs are generally owned by the state/government, and are central water processing locations that receive all kinds of waste-water from a variety of users and public sewage systems. POTWs treat those effluents and, in theory, emit "cleaned" water back to waterways. Despite treatment, emissions from POTWs include numerous pollutants. While many of those pollutants are legally allowable, they nevertheless pose ecological and human health concerns, indicating that applicable regulations may not be stringent enough to protect eco-system and public health, and that those emissions contribute to ecological disorganization (Lynch et al., 2013). In that context, we argue that POTW emissions can also be examined as examples of green crime, and more specifically as green-state crimes. Illustrating these points, we examine POTW emissions across US states employing US Environmental Protection Agency (EPA) emission data extracted from the discharge monitoring report (DMR) for 2014. To contextualize those data and the analysis of water pollution, we review relevant laws regulating POTW water pollution in the USA, the health and ecological consequences associated with POTW emissions, and conceptualize POTW emissions as green and green-state crimes that promote ecological disorganization.

\section{POTW emissions as green and green-state crimes}

Criminological research on POTWs offers a unique opportunity to examine how state behaviours and green crimes/harms intersect, and how POTW emissions contribute to ecological disorganization. As state-owned/contracted facilities, POTWs can legally discharge pollutants from treated waste water streams that have adverse ecological impacts without necessarily violating the law. Green criminologists have posed numerous definitions of green crime that expand beyond the scope of the law to identify behaviours that cause ecological, nonhuman species or human health harms as green crimes (for example, Lynch, 1990; Beirne and South, 2007; White, 2009; Brisman and South, 2013). Since POTW emissions can include legally allowable yet harmful pollutants, it is necessary to look beyond the law to conceptualize those emissions as green crimes. Of particular relevance here is Walters' (2010: 180) definition which "extends existing definitions of environmental crime to include licensed or unlawful acts of ecological degradation committed by states and corporations." This definition of green crime applies to POTWs since their "licensed or unlawful" emissions at state sanctioned facilities generates "ecological degradation" or what is also called ecological disorganization (Schnaiberg, 1980), and contributes to the impairment of waterway ecosystem health.

Walters' reference to "states and corporations" suggests that green and state/corporate crimes can intersect, an issue specifically addressed by Moloney and Chambliss (2014). Drawing on Mullins and Kauzlarich's (2000) definition of state crime and a long history of efforts to expand and problematize the definition of crime within criminology (Moloney and Chambliss, 2014: 326-327), Moloney and Chambliss (p. 325) argued that social harms generated by the state should include, as green criminologists posit, harms against non-human entitiesnon-human animals, plants and ecosystems. That approach also situates this conceptualization of green crime within a long tradition of state crime research within criminology (for example, Michalowski and Kramer, 2006; Rothe, 2009; Chambliss et al., 2010; Rothe and Mullins, 2011). Building on those observations, the present study draws attention to the types and quantity of water pollution emitted by POTWs as representing an area of research where the concepts of state crime and green crime intersect one another.

Drawing on research in environmental sociology and ecological Marxism, and situating the analysis of green crime and justice within a political economic approach, green criminologists have argued that green crime and injustice involve behaviours that generate ecological disorganization-or as conditions that disrupt and damage ecosystems and their functions (Lynch et al., 2013). Ecological disorganization can occur in various ways. In the present study, we focus on forms of ecological disorganization caused by adding pollution (called ecological additions) to ecosystems. In theory, POTWs accept waste water, treat that water and return it to waterway ecosystems. The treated water, however, continues to contain pollutants, and those pollutants can disrupt the normal state of waterway ecosystems, cause disruptions in the operation of those systems, and hence generates ecological disorganization-what Walters' called "ecological degradation." The extent of ecosystem disorganization in waterways depends on the volume of pollutants that are added. The volume of ecological additions varies across states, and across individual waterway ecosystems used as waste-water basins, and our analysis does not address this problem in any specific waterway, but rather provides a general idea of the extent of this form of ecological disorganization. From a political economic vantage point, this form of ecological disorganization should be expected to be widespread, but also to reflect the distribution of various dimensions of the capitalist treadmill of production (ToP) across states. Thus, in states where, for example, the ToP is agriculturally concentrated, POTW emissions will be likely to contain elevated levels of pollution associated with agricultural production, while in urban areas, they will reflect industrial pollution concentrations. This hypothesis concerning the relationship between POTW pollution and the capitalist ToP could be empirically tested with disaggregated POTW data that are 
connected to census data of various types. It is not our intent to test that hypothesis here but rather to explore the more general observation concerning the ecological disorganizing impacts of POTW pollution. We also illustrate that issue in part by reviewing research on the ecological effects of the most prevalent pollutants emitted by POTWs later in this article.

\section{Background: POTWs}

POTWs are state-owned or contracted facilities that process waste water from a diverse array of sources including residential areas, sewers, storm water and may sometimes include industrial waste effluent. After treatment, POTWs return processed wastewater to waterway ecosystems. In the USA, POTWs must comply with Clean Water Act (CWA) and National Pollution Discharge Elimination System (NPDES) regulations in an effort to discharge treated effluent emissions that are environmentally safe. Technically, under US laws, industrial facilities are not supposed to emit effluents to POTWs, though US EPA allows states to side-step this requirement by issuing "General Permits" under the NPDES instead of under more stringent CWA requirements, and can usually do so when industrial waste waters are pretreated (Gaba, 2007).

Though regulated by law, POTWs may nevertheless emit polluted processed water into waterways. This occurs even when POTWs are in compliance with their emission permits, since those permits are not "zero" standard emission rules and allow some level of pollution to be emitted. Despite national regulation under the CWA and NPDES, POTW permits vary across states and are not uniform, with states playing an important role in determining how CWA requirements apply to POTWs within their state (see, Lynch et al., 2014, for discussion).

Little research has addressed the quantity and types of emissions released by POTWs, and has been more likely to examine the technical aspects of controlling POTW emissions (for example, Upadhyay et al., 2011; Lee et al., 2012; VidalDorsch et al., 2012). As Rahman et al., (2010) noted, while researchers have empirically examined factors affecting other forms of environmental compliance/noncompliance, few studies examine POTW water pollution. Addressing that issue, Rahman et al., (2010) examined determinants of POTW noncompliance, generating what we can say are "expected results." For example, they found that larger POTWs have more noncompliance violations while privately owned water treatment facilities have lower rates of violation (perhaps, we would hypothesize, because the latter usually serve smaller populations, are more likely to be in rural areas, and process less industrial waste water). Examining POTWs in the state of Kansas, Earnhart (2004) found that $32 \%$ had expired permits, and that emissions sometimes exceeded permit requirements by as much as $1453 \%$. Earnhart also noted that during the nine years examined, POTW emission regulations were rarely enforced, with only 43 enforcement actions. Examining POTW emissions and regulation enforcement is also important because, like other pollutants, POTW emissions are likely to be unequally distributed. Using data on water quality from San Joaquin Valley, California, Balazs and Ray (2014) describe the social justice implications of access to clean water, and in particular to publicly treated drinking water. They found that public drinking water quality and water treatment emissions were unequally distributed across race, class and ethnic lines.

Little research has been published examining the volume and types of emissions POTWs emit. The present study addresses these issues by examining POTW water emissions for the most often emitted pollutants (top pollutants) across 48 US states for 2014. These emissions, while largely legal, tell us something about the role state facilities charged with processing waste water have in constraining/facilitating water pollution, and serve as an example of the complex ways in which state and green crimes intersect and generate ecological disorganization. Before discussing these data, we provide some brief background material on the history of water pollution laws in the USA as context.

\section{History of US water pollution laws}

Historically, interest in the problem of water pollution emerged more than two centuries ago when the link between water pollution, sanitation and major disease epidemics began to emerge (http://oceanservice.noaa.gov/education/kits/pollution/ 02history.html). Laws related to the control of water pollution, however, took significantly longer to develop (Andreen, 2003). The first US federal law specifically designed to address water pollution was the Federal Water Pollution Control Act (FWPCA) of 1948 (P.L. 80-845, 62 Stat. $1155 ;^{1}$ Lynch et al., 2014). At that time, there was growing awareness that dumping raw sewage and industrial waste into waterways was creating public health problems and threatening waterway and wildlife health. Due to concerns that federal regulations should not interfere with state's rights, FWPCA regulations applied to interstate waterways, but only offered encouragement to improve waterway quality by limiting pollution without the use of any specific pollution limits or penalties (the law allowed only for abatement actions; Barry, 1970).

The next major step in controlling water pollution in the USA was the CWA of 1972, which followed the creation of the US EPA in 1970. Technically, the CWA amended the FWPCA (Lynch et al., 2014). The CWA established the first rules for regulating water pollution discharges, and gave the US EPA authority to establish wastewater standards for industries, and for all wastewater receiving waterways in the USA. The CWA required that all "persons" who discharged pollutants into waterways obtain a pollution permit. The permit system allowed EPA to track pollutants to their sources, and monitor the volume of waterway pollution being discharged, and in doing so to obtain a better understanding of the kinds and quantities of pollutants being emitted into waterways. This information could then be used to limit/regulate waterway emissions to improve water quality and decrease the public health/ecosystem impacts of waterway pollution discharges-or in our terminology, to decrease the ecological disorganization effects of water pollution emissions. These efforts were related to the policy objectives of the CWA, which was to make all US waterways "fishable and swimmable" by 1985 , an objective that has yet to be attained 32 years later. Indeed, according to US EPA's assessment (https://ofmpub.epa. gov/waters10/attains_nation_cy.control), 55.5\% of streams and rivers, $70.3 \%$ of reservoirs and ponds, $78.3 \%$ of bays and estuaries, $88.9 \%$ of coastal shorelines, and $53.4 \%$ of wetlands are currently impaired and, as a result, fail to meet CWA criteria.

POTWs are primarily regulated under CWA Titles II and VI (33 U.S.C. $\$ 1281,33$ U.S.C. $\$ 1381$ ). To facilitate wastewater treatment, the EPA provides grant assistance to construct POTWs. Industry is normally expected to maintain separate wastewater treatment systems. However, industrial users (IUs) and significant industrial users may emit wastewater to POTWs when that water has been pretreated and meets standards specified in the National Pretreatment Program (40 CFR 403). IUs are prohibited from discharging certain pollutants to POTWs (40 CFR 403.5) unless the POTW has installed equipment for processing excepted IU water emissions.

The EPA also established secondary standards for POTW emissions under NPDES. Secondary treatment standards include the use of technology-based biological treatment of wastewater and apply to all POTWs. These standards are assessed through 
the use of chemical measurement of POTW emissions (that is, biochemical oxygen demand (BOD), carbonaceous biochemical oxygen demand (CBOD and CBOD5) and total suspended solid (TSS) measures), measures we used below in our analysis.

States receive a permit to operate POTWs from the EPA. Each state's permit must respond to the specific water pollution problems within that state and address water treatment solutions appropriate to that state, unless an exception is granted. As a result, there are no general, national statutory standards concerning POTW emissions.

Perhaps due to the complexity of POTW regulations and variability in those regulations across states, no prior study has examined national emissions by POTWs. Instead, studies have examined individual POTW's environmental effects, POTWs in a single state (Earnhart, 2004; Maruya et al., 2012, 2014; Daigger et al., 2014), the effect of POTW emissions on specific species (Vidal-Dorsch et al., 2013a,b), and the processing of specific pollutants at POTWs (for example, Flippin et al., 2014; Balasubramani and Rifai, 2015). In the present study, we examine national or aggregated US POTW emissions to address the general impact of POTWs on US waterways and how those emissions by state facilities contribute to ecological disorganization/green crimes against ecosystems and constitute green-state crimes.

Data. For the current study, data on water pollution emissions by POTWs by state were collected from the US EPA DMR pollutant loading tool (PLT; http://cfpub.epa.gov/dmr/ez_search.cfm). The PLT produces data on a state by state basis, which were then aggregated for the year 2014. Not all states were included in the 2014 PLT data for POTWs, and due to missing data, we were only able to collect data for 48 states. $^{2}$ These data were supplemented with indicators from the US Department of Agriculture to create standardized pollution measurements. The US EPA estimates that the nation's POTWs treat and release 32 billion gallons of wastewater each day.

The data used in this study quantify emissions, not violations of law, and because they quantify emissions, are indicators of the concept of green crime as ecological disorganization. As noted earlier, green crimes often expand beyond the scope of law, and even legally allowable behaviours can create ecosystem, human and non-human animal harms that can be defined as green crimes. In the current case, we suggest that evidence of those green crimes is reflected by both the quantity of POTW emissions and the harms associated with POTW emissions. Information on the harms associated with POTW emissions are summarized later in this article.

Although POTWs emit numerous pollutants, the majority of those emissions involve forty-four pollutants commonly emitted by POTWs. We identified those forty-four pollutants by recording the top ten pollutants in pounds emitted by POTWs in each state. Our data describes two measures of POTW pollutants: (1) the pounds of the top ten emitted pollutants within each state in pounds; and (2) pounds of the top three toxic pollutants in each state in toxic-weighted pound equivalents
(TWPE). These data are, following applicable regulations, selfreported by POTWs. We focused attention on the top ten pollutants in each state because we estimated from these data that those pollutants accounted for more than 99\% of all POTW emissions in pounds. We used the TWPE data to illustrate the kinds of dangerous pollutants POTWs emit. Both measures are indicators of different dimension of ecological disorganization.

Data on the distribution of POWTs across states along with measures of POTW types are shown in Table 1. There were 15,562 POTWs for the 48 states in the sample, with a mean of 324.2 POTWs per state ranging from $N=2$ (Hawaii) to $N=1261$ (Texas). Twenty states had POTWs in excess of the mean.

\section{Results}

Aggregate emissions. The current study measured aggregate POTW emissions for the top ten pollutants emitted by each state (in total, 44 chemicals), and thus this estimate is not an estimate of the total pollution POTWs emit. The pounds of pollutants emitted by POTW using our measure was more than 197.48 billion pounds-which we estimate was $>99 \%$ of all POTW emissions in 2014.

Across states, POTWs emitted between 8.8 million to 185.2 billion pounds of pollutants during 2014. The mean pounds emitted were 4.114 billion. Nine states' POTWs emitted pollutants in excess of the mean, and the mean was significantly skewed by Minnesota's POTW emissions (more than 185 billion pounds)-about 46 times the mean. The vast majority (99.6\%) of Minnesota POTW emissions were total dissolved solids (TDSs). ${ }^{3}$ (See Supplementary Appendix A for pounds of top ten pollutants emitted by each state, and an indicator of pounds per acre of state land). The majority of pollutants emitted by POTWs across states involved two pollutants: TDSs and TSSs.

Emission requirements. Under the NPDES (40 CFR 122.44 (a) (1)), states must report discharges from POTWs to the EPA. In turn, states typically obtain those data from POTW selfmonitored emissions. Given local water quality issues, few POTWs $(N=213 ; 1.4 \%)$ are required to continuously monitor water emissions by EPA. As Table 1 indicates, however, the majority (77.1\%) of POTWs have effluent limits. This data suggests that US EPA, though charged with monitoring and assessing US water quality, rarely requires individual POTWs to continuously monitor their emissions, even though, as noted earlier, a significant portion of US waterways fail to meet CWA requirements that were supposed to be met by 1985 . In this case, it seems, EPA is not regulating POTW emission as stringently as it might to in an effort to meet CWA imposed water quality standards.

Top pollutants. Table 2 displays the distribution of the top ten pollutants across all 48 states, and displays a count of the number of times a pollutant is recorded as the top pollutant in each state $(N=48)$. States were most likely to list TDSs as their top pollutant, followed by TSS, and 31 states $(64.6 \%)$ listed one of these two pollutants as their top pollutant. Three pollution categories

Table 1 | Distribution of POTWs across states

\begin{tabular}{lllll} 
& POTWs & Major POTWs & N monitored & N with effluent limits \\
\hline Number & 15,562 & $4334(27.8 \%)$ & $213(1.4 \%)$ & $11,998(77.1 \%)$ \\
Mean/state & 324.2 & 90.29 & 4.4 & 250.0 \\
Minimum/state & 2 & 2 & 0 & 2 \\
Maximum/state & 1261 & 451 & 148 & 1191 \\
\hline
\end{tabular}


Table 2 | Top pollutants across 48 states

\begin{tabular}{lclc} 
Classification & $\begin{array}{c}\text { No. of } \\
\text { states }\end{array}$ & Classification & $\begin{array}{c}\text { No. of } \\
\text { states }\end{array}$ \\
\hline $\begin{array}{l}\text { Dissolved solids (TDS) } \\
\text { Suspended solids }\end{array}$ & 18 & Carbonaceous BOD & 1 \\
(TSS) & 13 & COD & 1 \\
Chloride & 4 & Oxygen demand & 1 \\
Nitrogen & 3 & Sulfate & 1 \\
BOD & 3 & Kjeldahl nitrogen & 1 \\
Ammonia & 2 & & \\
\hline
\end{tabular}

(nitrogen, ammonia and Kjeldahl nitrogen pollution) measured some dimension of nitrogen pollution, a serious water pollution concern because excessive nitrogen can cause eutrophication-a lack of water oxygen content that can lead to the death of aquatic species. Six states (12.5\%) listed nitrogen related pollutant as their top pollutant. In addition, three states listed BOD, another indicator of water oxygen content, as a top pollutant. BOD measures organic water pollution and water quality. A related measure, Carbonaceous BOD (CBOD; also an oxygen demand indicator) was reported as the top pollutant in one state. Oxygen demand related measures (nitrogen/BOD/CBOD) are important dimensions of water pollution and quality. In sum, 41 states listed the above six pollutants as their top pollutant.

Aggregation, top ten pollutants. Across states, the aggregation of the top pollutants from each state yielded a total of 44 different pollutants. Table 3 shows only the most frequent of these pollutants, and the number of states reporting those pollutants as being among their top ten pollutants. Table 3 can be interpreted as displaying the number of states out of 48 that listed each pollutant among its top ten pollutants. With respect to the previous discussion of eutrophication, 43 and 42 states, respectively, listed CBOD and BOD among their top ten pollutants-indicators that in most states, POTW emissions may be seriously impacting waterway oxygen content, and generating potentially serious waterway ecological disorganization such as the potential for eutrophication. Additionally, a number of states report ammonia $(N=42)$, phosphorus $(N=37)$, nitrogen $(N=30)$ and inorganic nitrogen $(N=28)$ as top ten pollutants. These pollutants can disorganize waterway ecosystems by promoting excessive plant growth. It should also be noted that across the top ten pollutants, states report emitting in excess of 2 billion pounds of monitored effluent emissions into the nation's waterways.

Toxic-weighted pound equivalents. The PLT tool also contains data on TWPE. The TWPE is calculated using the toxic weighting factor (TWF) for pollutants that are known to be toxicants, therefore not all POTW emissions have a TWF. In the present study, we recorded the top three TWPEs for POTW effluents in states, and then aggregated those data to create Table 3 . The TWPE can be viewed as a measure of the most toxic chemicals emitted by POTWs.

Twenty-seven different chemicals with toxic properties were identified as being emitted by POTWs using this indicator. Because we limited this assessment to the top three TWPE chemicals in each state, the data in Table 3 present only a limited picture of highly toxic pollution emissions by POTWs. In cases where the quantities of TWPEs emitted appear quite small, one must remember that these are highly toxic chemicals that, despite their small quantity, could have serious adverse impacts on local waterway aquatic species (especially for sensitive species). The most widely released toxin in this group was residual chlorine,
Table 3 | Most frequently discovered pollutants in POTW emissions across top 10 pollutants and states

Total suspended solids

Carbonaceous BOD

Ammonia

BOD

Phosphorus

Nitrogen

Total dissolved solids

Inorganic nitrogen

Residual chlorine

Table 4 | Ranking of top three toxic-weighted pound equivalent emissions across states (alphabetic listing)

\begin{tabular}{|c|c|c|c|c|}
\hline Chemical & $1 s t$ & 2nd & $3 r d$ & Total \\
\hline $1,2,3,6,7,8$-Hexachlorodibenzofuran & 0 & 1 & 0 & 1 \\
\hline 2,3,7,8-Tetrachlorodibenzo-p-benzene & 1 & 0 & 0 & 1 \\
\hline Aluminum & 0 & 1 & 0 & 1 \\
\hline Ammonia as $\mathrm{N}$ & 1 & 8 & 10 & 19 \\
\hline Arsenic & 2 & 1 & 2 & 5 \\
\hline Benzidine & 0 & 1 & 1 & 2 \\
\hline Cadmium & 3 & 2 & 3 & 8 \\
\hline Chlordane & 0 & 0 & 1 & 1 \\
\hline Copper & 5 & 11 & 8 & 24 \\
\hline Cyanide & 0 & 1 & 2 & 3 \\
\hline Deldrine & 2 & 0 & 0 & 2 \\
\hline Dissolved nitrate & 1 & 0 & 0 & 1 \\
\hline Floride & 0 & 1 & 0 & 1 \\
\hline Iron & 0 & 0 & 1 & 1 \\
\hline Lead & 0 & 3 & 3 & 6 \\
\hline Magnesium & 0 & 1 & 0 & 1 \\
\hline Mercury & 2 & 4 & 4 & 10 \\
\hline $\mathrm{NH3}$ & 0 & 1 & 0 & 1 \\
\hline Nickel & 0 & 0 & 1 & 1 \\
\hline$p, p^{\prime}-D D T$ & 0 & 1 & 0 & 1 \\
\hline PCBs & 2 & 1 & 2 & 5 \\
\hline Residual chlorine & 28 & 1 & 6 & 35 \\
\hline Selenium & 1 & 1 & 0 & 2 \\
\hline Silver & 0 & 1 & 1 & 2 \\
\hline Sulfide & 0 & 1 & 0 & 1 \\
\hline Toxophene & 0 & 1 & 0 & 1 \\
\hline Zinc & 0 & 4 & 2 & 6 \\
\hline
\end{tabular}

which was long ago identified as having adverse health consequences for aquatic species (Brungs, 1973; Bellanca and Bailey, 1977; Helz and Nweke, 1995). In addition, residual chlorine may also pose health risks to humans at elevated concentrations (Mills et al., 1998). The second most prevalent toxin in this group was copper, which also has adverse impacts on aquatic species and, because of its toxic properties, is also used as an ingredient in some insecticides/pesticides/fungicides (Brix et al., 2001) (See Table 4).

Pollution concentrations. POTW emissions data can also be used to assess various pollution concentrations across states. As noted above, Minnesota emitted the largest quantity of total top ten pollutants (185 billion pounds). Those emissions were 63.8 times larger than POTW emission reported by the state second on the list, Ohio (2.9 billion pounds), and 75.9 times larger than the third highest POTW pollution emitter, California (2.446 billion pounds). There is a significant decline in the pounds of top ten pollutants reported by POTWs in the next grouping (state 
reporting between 501 to 578.2 million pounds of emission: Arizona, New York, Nevada, West Virginia, Pennsylvania and Indiana). At the opposite end of the spectrum, the lowest level of POTW emissions were reported in Maine, which released "only" about 8.8 million pounds of top ten pollutants, followed by New Hampshire (10.49 million pounds), and South Dakota (10.8 million pounds). Future research can explore whether levels of emission by POTWs across states is related to the distribution or composition of the ToP (see, Stretesky et al., 2013).

Standardized emission measures. In the aggregate the top ten pollutants represent a significantly large quantity of waterway pollution and ecological disorganization potential. Other measures of those pollutants are useful to contextual those emissions. One approach is to standardized POTW pollution emission per miles of rivers and stream per state, or as pounds of pollution per state area (in acres). Water-based POTW emissions are difficult to quantify given that in addition to rivers and streams, they may also be emitted to lakes and ponds, and in some states, oceans and estuaries. Some of those water bodies are measured in miles, and others in acres, requiring significant effort to convert those data to make them comparable. A simpler standardization employs pounds of POTW pollutants per state acre, which may not be the most useful standardization for POTW pollution since, after all, those emissions occur in waterways. Pounds of POTW emissions per acre data for each state are found in Supplementary Appendix A. In Supplementary Appendix A, the highest concentrations of POTW emissions are found in Minnesota (2.13 million pounds per acre), Ohio $(64,837)$, West Virginia $(22,431)$, New Jersey $(19,858)$ and California $(14,943)$. Here, as with the total pounds of emission, Minnesota leads the way and emissions fall significantly for state's outside of Minnesota. Following standardization, the order of the remaining top polluters change. States generating the least POTW waste per acre include: Alaska (37.15), New Mexico (102.88), Wyoming (129.25), South Dakota (140.17) and Maine (248.78). Here too, standardization alters the list of smallest pollution levels by state when compared with total pounds of emissions. Criminologists should be quite familiar with standardization and its uses in relation to, for example, measuring crime or incarceration rates. In the latter cases, the total number of crimes is less preferable to measuring crime per 100,000 population, though something can be learned from examining both types of measures. ${ }^{4}$

Water quality assessment. The data above tell us something about the general problem of POTW pollution in the USA. It is also important to consider the possible human (public health) and ecological effects of those pollutants. Here, we review that issue in brief as another example of how POTW emissions constitute green-state crimes that cause ecological disorganization effects. For this portion of the analysis, we limited the discussion to a review of prior research on pollutants POTWs emit that were most often identified in the empirical portion of our analysis.

Total dissolved solids. TDSs are chemicals and ions that pass through filters with pores of approximately 2 microns, and include calcium, carbonate and bicarbonate, chlorides, iron, magnesium, nitrate, phosphorus, sodium, sulphur and other ions/particles such as salts, organic matter and minerals (Weber-Scannell and Duffy, 2007). TDS emissions can produce toxicity in three ways: by increasing water salinity; by altering the ion composition of water; and by affecting the toxicity of individual ions (WeberScannell and Duffy, 2007). These effects occur because the level of dissolved solids in water affects the rate of flow of water into and out of an organism's cells, affecting the balance of chemicals and ions at the cellular level. Extant research indicates that elevated levels of dissolved solids in waterways can: retard the growth or cause the death of aquatic species; cause a decrease in waterway species diversity as water salinity increases; degrade water clarity and hence cause a decline in plant photosynthesis; promote chemical reactions between toxins and dissolved solids; cause dehydration, and in extreme cases death in species through the laxative effects of exposure to water with high TDS concentrations (Weber-Scannell and Duffy, 2007).

Total suspended solids. TSSs are small particles that do not settle when water is left standing and can pass through a filter with pores of 0.45 microns. TSS do not ordinarily present direct health problems, but interfere with efforts to disinfect water, and can provide a medium for the growth of microbes/bacteria. TSS have also been associated with a decline in fishery resources and extensive "degradation of aquatic environments" (Bilotta and Brazier, 2008); to interfere with water clarity, which decreases photosynthesis, causing a decline in water-biomass and contributing to eutrophication (US EPA, http://water.epa.gov/type/ $\mathrm{rsl} /$ monitoring/vms58.cfm); and to declining species biodiversity among species less tolerant to elevated TSS levels (Kemp et al., 2011).

Carbonaceous biological oxygen demand (CBOD). CBOD measures the ability of waste waters to reduce or deplete the oxygen content of receiving waters. Water emissions with high organic content increase the use of oxygen for oxidation, potentially decreasing species richness and causing eutrophication (Ganoulis, 2009).

Biological oxygen demand (BOD). BOD measures the amount of dissolved oxygen needed by microbial organisms for the metabolism of organic compounds in water (Sharma, 2009:431). As BOD increases, available oxygen declines. This outcome can limit the growth of some aquatic species; increase the growth of harmful water-based bacteria; decrease the presence of microbes in the aquatic food-chain reducing species diversity and concentrations; promote poor water quality; and cause eutrophication (Sharma, 2009; US EPA, http://water.epa.gov/type/rsl/ monitoring/vms52.cfm). These pollutants often enter POTWs through urban sewer systems and via farm run-off rich in fertilizers and organic matter (for example, leaves, lawn cuttings).

Ammonia. According to the US EPA (2013), "Ammonia is ... one of the most important pollutants in the aquatic environment not only because of its highly toxic nature, but also its ubiquity in surface water systems." The primary source of ammonia in wastewater is from agricultural and industrial production. Ammonia can be toxic to aquatic life forms. Elevated levels of ammonia are known to have adverse consequences on a variety of species of fish, snails, amphibians, mollusks and invertebrates (for example, Mayes et al., 1986; Clearwater et al., 2014).

Phosphorus. Agricultural and urban run-off are major contributors to waterway phosphorus pollution. Phosphorus pollution has a significant role in waterway eutrophication through excessive production of algae (Correll, 1998; Bennet et al., 2001) and may appear abruptly once an absorption level is surpassed (Bennet et al., 2001). Much freshwater ecosystem phosphorus content results from excessive phosphorus inputs into ecosystems through fertilizer run-off and animal feed operations (Bennet et al., 2001), which can cause phosphorus run-off into waters processed by POTWs.

Nitrogen. Nitrogen pollution presents ecological problems similar to those associated with phosphorus pollution including excessive 
water nutrients, algae growth, and eutrophication, as well as waterway acidification, and a decline in acid-sensitive species (Driscoll et al., 2003). Agricultural run-off and the widespread use of fertilizers on lawns, public parks/spaces, and golf courses are significant non-point sources of water-based nitrogen pollution (Carpenter et al., 1998), and Driscoll et al., (2003) estimate that anthropogenic nitrogen pollution has doubled the volume of reactive nitrogen in ecosystems.

\section{Discussion}

The data and environmental health concerns reviewed above indicated that across US states, POTWs release significant quantities of pollutants into waterways potentially causing extensive ecological disorganization, a green crime (Lynch et al., 2013). POTWs do not generate the majority of those pollutants with the exception of pollution residuals related to water treatment methods. For example, in a study of mercury pollution in New York City's harbour, Cerreno et al., (2002) note that POTWs emit significant quantities of mercury pollution into the harbour. That pollution, however, does not originate in POTWs (POTWs can contribute to chemical interactions that convert inorganic mercury into more reactive methylmercury). Rather, the emitted mercury pollution is received by POTWs from numerous sources including dental facilities, hospitals, laboratories, and households; although the greatest source of mercury contamination of the harbour is landfill run-off. Nevertheless, the fact that POTWs are routes for environmental pollution raises a question about the responsibilities of the state with respect to its environmental (ecosystem and wildlife) and public health protection responsibilities. This pollution pathway through POTWs is also, we would suggest, part of the political economic organization of capitalism and the ToP.

Individual states take the responsibility to protect public and ecological health more or less seriously than others. As Sigman (2002) noted, while many environmental regulations are federal in origin, responsibility for monitoring and enforcing POTW regulations often falls to states because in the USA, states can request authorization to monitor and enforce POTW regulations. Although state POTW permits are approved by the US EPA, Sigman states that there is substantial discretion involved in preparing and approving CWA permits and EPA does not apply a single, uniform standard for water pollution emissions across all states. Indeed, while federal guidelines impose minimum pollution standards, EPA can modify those requirements depending on existing water quality concerns within a state and after determining whether POTW discharges impact already "impaired waterways." As Sigman noted "(p)ermits are subject to negotiation between polluter and regulator and to public comment periods ...." Using data for NPDES permits for five pollutants (cadmium, copper, lead, mercury and zinc), Sigman found considerable variability in EPA-imposed water discharge limits. For cadmium, the least stringent state requirement was four times lower than the most stringent state requirement; for copper, 38 times lower; for lead 312 times lower; for mercury, 750 times lower; and for zinc, 60 times lower. With respect to the issue of state responsibility for protecting the ecosystem and public health, we can see from POTW emissions data that some states take more and some states much less responsibility for maintaining healthy environments through POTW emissions.

In his analysis of CWA permits, Sigman argued that states have different rationale for implementing state monitored/enforced water pollution control programs. States may be seeking to stream-line regulations, or may seek to implement more or less stringent regulations to attract or repel certain types of industries. Here, one could argue that states make a trade-off between economic development and environmental protection. This scenario is possible across states precisely because the US EPA authorizes different permit standards across states. Under these conditions, some states are willing to impose lesser environmental protection requirements to attract industry at the cost of increased environmental pollution that potentially reduces ecosystem and public health.

One solution to this problem would be for the US EPA to apply more consistent or uniform pollution standards. However, Sigman suggests that this is unlikely since once a state's system is approved by EPA, it is nearly impossible for EPA to revoke the state's permit. Sigman uses the example of Arkansas to illustrate this point: "Arkansas refuses to impose federal discharge limits and monitoring requirements for municipal water pollution sources because they are "too strict" and would subject the state to litigation. The regional EPA office says its "only recourse would be to take back responsibility for the program-an unrealistic option" .... Thus, once authorized, states have quite a free hand to conduct (or ignore) the program."

From a technological/scientific perspective, it is highly unlikely that POTWs can prevent the emission of all pollutants into waterways and that some level of POTW pollution is, therefore, inevitable. Despite that inevitability, states could still engage in "best efforts" to provide the most efficient treatment of wastewaters before they are emitted into ecosystems. Why do states/ governments fail to promote enhanced water treatment at POTWs, thereby contributing to water pollution? There are three possible explanations.

First, in neo-liberal societies - those with a capitalist political economic system-citizens prefer minimal regulation, whether they are individuals, corporation or other private business entities, and research on this issue suggests that income and environmental concern are inversely related (Earnhart, 2004; Lo, 2014). Responding to public desires, states maintain minimal environmental regulations necessary for the protection of some unspecified level of ecosystem and public health (Earnhart, 2004). How a state makes a determination concerning adequate wastewater treatment is open to debate. However, in a neoliberal regulatory environment, regulated entities are regularly invited to comment on proposed environmental regulations, perhaps creating a state preference for crafting environmental regulations around that portion of the "community's" views on environmental matters (Coffey and Marston, 2013). Because the views of citizens are not monolithic and vary from state to state, citizens (including corporations) in some states have a preference for greater environmental protection than citizens in other states leading to differentials in cross-state environmental regulations, and in the case of the current study, is perhaps evident in the quantity of environmental pollutants emitted by POTWs across states. Thus, in its regulatory role and in its role as protector of citizens and ecosystems, the state acquires the duty to protect ecosystems and public health as well as corporate interests, and "chooses" (in neoliberal theory) or is "forced" (an idea consistent with structural analysis) to do so in different ways within the governance context of any given state (for example, see various chapters in Braithwaite and Levi, 1998).

The above view also represents a generic "democratic" theory of governance, and paints a picture of environmental regulation as a compromise between competing interests and values with the state as arbitrator. That view fails to ask whether in striking such a compromise, the state has met its duties to sufficiently protect ecosystem and public health. The problem with asking this question is that one must have some rationale or measurement for assessing whether or not the state's regulatory behaviour (or in this case, its polluting behaviour) is sufficient to protect ecological and public health. With respect to the specific issue of 
pollution, such rationales are easily mustered from scientific studies, which can and have been used to determine the level at which exposure to pollution and the accumulation of pollution become ecosystem and public health problems, as previous green criminological studies illustrate (see examples in Lynch and Stretesky, 2014). In asking (and answering) this type of question concerning the efficacy of state pollution control practices, two additional positions concerning the assessment of POTW pollution emissions, which we suggest relate to numerous arguments green criminologists have made about defining the parameters of green crime, harm and justice (Lynch and Stretesky, 2003; Walters, 2006, 2007; Brisman, 2008; Lynch et al., 2013; Ruggiero and South, 2013a, b; White, 2013; Sollund, 2015; White and Kramer, 2015) emerge. The first of these questions addresses whether pollution emissions from POTWs can be conceptualized as green crimes/harms. The second involves questions about whether state emissions from POTWs are a form of ecological injustice, and whether such emissions are unequally disbursed and have unequal adverse consequences for citizens related to the racial, ethnic and class composition of neighborhoods and communities near POTW pollution receiving waterways.

With respect to crime, Ruggiero and South's (2013a, b) analysis of the intersection of toxic state-corporate crimes contains one mechanism for understanding the polluting behaviour of stateowned POTWs as a green crime. Ruggerio and South assert that "in general, hegemonic discourses around "growth and freedom" have, during the last few decades, intensified the potential destructiveness of enterprise," and when coupled with neo-liberal economic and governance polices have contributed to the state's tendency to treat pollution as "accidental, unintentional and external" (p. 12). In our view, this assertion implies that the neoliberal/capitalist state has a role in facilitating ecological disorganization. For Ruggerio and South, in this neo-liberal political economic context the state cannot establish environmental rules that prevent economic expansion (which is also a requirement included in many US environmental regulations, see, Lynch, Burns and Stretesky, 2014 for examples). Ruggerio and South apply this argument to an analysis of state-corporate green crimes in the oil, asbestos and chemical industries to illustrate how states facilitate green corporate crimes. Unfortunately in the examination of state-owned POTWs, such an analysis, while appealing due to its state-corporate-green crime link, does not appear to readily apply to POTW pollution since POTW emissions have, at first glance, little connection to, for example, preserving economic expansion. However, as we noted earlier, POTW regulations are state-based and the specific regulations that apply to POTWs vary across states. States can, as Sigman argued, promote weak CWA regulations with the intention of promoting economic growth. Empirical studies by green criminologists also suggest that environmental regulations are ineffective in controlling environmental violations and pollution, and that in particular, in the political economic context of capitalism, environmental regulations are ineffective mechanism for constraining the growth of the ToP or ToP generated ecological disorganization (Long et al., 2012; Stretesky et al., 2013). Better understanding these issues requires further examinations of the emissions of pollutants by POTWs.

Equally important is the observation that states, because they are repositories of collective public responsibilities, have a duty to protect ecosystem and public health, and it can be argued, therefore, that the failure to do so contains the seeds of greenstate crime. In this case, the green crimes of the state related to POTW emissions involves promoting weaker water pollution and treatment standards than those derived scientifically, which would better protect ecosystem and public health. The EPA provides states with incentives to build and modify water treatment facilities through the State Revolving Fund (SRF) program. Whether or not states use those funds to build state of the art or minimally necessary water treatment facilities is an open question. The EPA provides guidance to states for the planning/designing of water treatment facilities (http://www3.epa. gov/npdes/pubs/ primer.pdf), but we were unable to locate information addressing whether states adopt any specific EPA recommendations. In addition, whether EPA recommendations for wastewater treatment represent the most recent technology and best available practice is also an open question. Recent studies suggest, for example, the use of absorption technology for water pollution treatment (Ali and Gupta, 2007), a technology which is not mentioned in EPA's guidance documents.

A second green criminological approach to assessing POTW water pollution emissions is to investigate whether such emissions constitute forms of ecological and/or environmental (in)justice. As White (2007) suggests, ecological justice focuses on issues related to environmental conservation including animal rights and biosphere conservation, while environmental justice involves an assessment of social justice in relation to exposure patterns to environmental hazards created by humans-issues that have been addressed empirically by green criminologists (Stretesky and Lynch, 1999, 2002, 2011; Lynch et al., 2004; Lynch and Stretesky, 2013). As the data reviewed above indicated, POTW emissions varied widely across states. To be sure, much of that variability has to do with the content of the waste stream received by POTWs, which varies across states and is dependent, we hypothesize, on the structure of the ToP across states. But, state POTW regulations also affect the content of the waste stream allowing, for example, industrial emissions to POTWs in some states while other states exclude those emissions and require separate industrial facility processing of waste waters. Regardless, the question that remains is whether the distribution of POTW emissions is also a function of the type of wastewater/sewage treatment a state selects. Our data cannot directly address that question. However, it is clear from the distribution of POTW pollution across states that some states may indeed provide better methods for processing waste waters, enhancing both ecological and environmental justice. Unfortunately, answering this question involves undertaking extensive and perhaps complex future empirical research. The issue of POTWs and environmental justice has rarely been mentioned in prior studies (Toeffel and Marshall, 2004; Wilson et al., 2008).

There is much future research that can be undertaken to further explore how state POTW emissions, green crime and environmental justice issues intersect, and how those issues require attention to the concept of green-state crime. As one example, the US EPA Pollution Discharge Monitoring Report Pollution Loading Tool can be used to extract data concerning the quantity of CWA Priority Pollutants, Comprehensive Environmental Response, Compensation and Liability Act (CERCLA) hazardous substances emissions, toxic release inventory (TRI) emissions, and radionuclide pollution emitted by POTWs. As a brief example, we employed the PLT to generate a list of CWA Priority pollutants emitted by POTWs in Alabama. The resulting list of top POTW generators of CWA Priority Pollutants in Alabama provide several indicators concerning the average and maximum concentrations and total pounds of CWA Priority pollutant at each facility. Data on total pounds for individual POTW Priority Pollutants can also be collected from the PLT. In the Alabama example, we selected data for the Slab Creek Wastewater Treatment Plant in Boaz. That data indicated that Slab Creek emits three CWA Priority Pollutants: copper, mercury and zinc. While the Slab Creek facility has a maximum allowable annual emission for copper of zero pounds, the facility emitted 
56.2 pounds of copper. Monthly reports for Slab Creek's copper emissions indicate the facility violated its permit concerning copper emissions. ${ }^{5}$ These data can be used for assessing POTW compliance with permitted emissions, an issue that has yet to be explored to our knowledge using these data. Use of data of this type is, in our view, extremely important to the further development of green criminology and for efforts to extend the penetration of green criminological research into the criminological mainstream given the long standing focus on quantitative data in mainstream criminology (see Lynch et al., 2017 for discussion).

\section{Conclusion}

This study examined POTW emissions as an example of green crime, illustrating the extent of this problem in the USA, and posed that this behaviour is a green-state crime that generates various types of ecological disorganization. Consistent with our argument, Moloney and Chambliss (2014: 320) argued that "encouraging green criminologists and state crime scholars to combine their resources and perspectives when analysing and explaining certain environmental harms stemming from state actions or inactions is not only timely, but beneficial in a substantive sense for each discipline, and in a practical sense for the societies we are embedded within."

Our study indicated that POTWs emitted large quantities of pollutants-nearly 200 billion pounds-to US waterways during 2014. The quantity of pollutants emitted varied widely across states, and as noted, POTW themselves do not generate the majority of those pollutants (except for those related to the treatment of waste waters), but receive those pollutants from various emission sources. Nevertheless, this raises a question about the stringency of wastewater treatment regulations within each state as guided by federal regulations, and whether states employ sufficient water treatment processes for the protection of ecological and public health. Equally important, we suggested that these emissions can be viewed as part of the intersection of green and state crimes, and that future studies should investigate environmental justice questions related to POTW emissions. Thus, our analysis has relevance to both the state crime and green crime literatures.

As Moloney and Chambliss noted, little attention has been paid to the intersection of green and state crimes. Their observation opens a potentially wide-range of behaviours to examination by both green criminologists and state crime researchers. Recent examples of the expansion of this type of research include criminological studies of climate change that illustrate how the state contributes or becomes involved in green crimes (Lynch et al., 2010; Bradshaw, 2015; White and Kramer, 2015; and various chapters in White, 2012).

Finally, while green criminologists have often cited water pollution as a general example of a green crime, few green criminological studies actually address the scope of water pollution crimes and the forms of injustice such crime pose, particularly through the use of quantitative data. Much future research remains to be done on this topic, and those efforts can draw on a wide range of scientific studies and evidence that has already been complied.

\section{Notes}

1 The US River and Harbors Act (RHA) of 1899, the oldest US environmental law, is often mentioned as a water pollution control Act. The Refuse Act section of RHA made it a misdemeanor to dump refuse into navigable waterways to prohibit dumping waste that prevented navigation of waterways, rather than to prevent pollution to protect ecological or public health (see US EPA's, "Explanatory Statement:
Implementation of the 'National Pollution Discharge Elimination System' Pursuant to Section 402, Federal Water Pollution Control Act Amendments of 1972.").

2 Data were missing for New Jersey for 2014, and instead the most recent data for New Jersey (2012) was used. Data were also missing for Vermont. There is no substitute data available for Vermont because it does not use the federal Permit Compliance System to report POTW emissions. Data for Kansas only represented POTWs on Indian Lands, and thus were omitted.

3 Suspecting that the total dissolved solids may involve a reporting error or perhaps new reporting requirements in Minnesota, we examined data from prior years. In 2013, Minnesota POTWs reported emitting more than 96.57 billion pounds of total dissolved solids, about one-half of the total reported in 2014. In 2012, those facilities reported emitting only 1.1 billion pounds of total dissolved solids; in 2011, Minnesota POTWs reported emitting only 297.2 million pounds of total dissolved solids. One potential reason for this increased reported of total dissolved solids in Minnesota was a change in monitoring and reporting requirements (see, http://www.pca.state.mn.us/ index.php/view-document.html?gid $=6267$ ).

4 We attempted to standardize POTW pollution relative to miles of rivers and stream within each states. As noted, this measure omits important dimensions of those emissions in some states such as coastal states, which may emit to estuaries and oceans, and Great Lake states or other states where significant emissions are made to large water bodies. Again, miles of rivers and streams and emissions to acres of lakes and estuaries are difficult to convert and compare. Nevertheless, we did perform calculations for pounds per mile of rivers and streams, and present only a few examples for the top and smallest polluters. Top POTW polluters include per miles of rivers and streams include: Minnesota (2 million pounds per mile), Ohio $(99,830)$, New Jersey $(26,855)$, West Virginia $(16,838)$ and Massachusetts $(15,057)$; while the lowest levels are found in: Alaska (67.7 pds/mile), New Mexico (112.96), Wyoming (116.24), Maine (227.16), and Mississippi (375.44). Future research should consider addressing additional aspects of water POTW emission to lakes, estuaries and oceans state-green crime. Such studies might also employ exact POTW locations and GIS software to assess the effects of POTW pollution on concentrations of human populations and the racial, ethnic and class composition of affect populations, specific waterways, sensitive ecosystem locations, in relation to sensitive wildlife habitat, fish breeding grounds, or in relationship to the distribution of endangered species.

5 In addition, we assessed the CWA Priority Pollutant emissions at the remaining nine Alabama POTWs. The results were as follows: Roanoke, no exceedances; Helena, no exceedances; Chase Area, four exceedances out of four measures for mercury; Orange Beach, no exceedances; Geneva, three exceedances; Phenix, no exceedance; Wright Smith, three exceedances for copper; Cullman, no exceedances; Huntsville Big Cove, four exceedances out of four test for mercury to be determined by further assessment.

\section{References}

Ali I and Gupta VK (2007) Advances in water treatment by absorption technology. Nature Protocols; 1 (6): 2661-2666.

Andreen WL (2003) The evolution of water pollution control in the United StatesState, local and federal efforts, 1789-1972: Part II. Stanford Environmental Law Journal; 22 (July): 215-294.

Balasubramani A and Rifai HS (2015) Occurrence and distribution of polychlorinated dibenzo-p-dioxins and polychlorinated dibenzofurans $(\mathrm{PCDD} / \mathrm{Fs})$ in industrial and domestic sewage sludge. Environmental Science and Pollution Research; 22 (19): 14801-14808.

Balazs CL and Ray I (2014) The drinking water disparities framework: On the origins and persistence of inequities in exposure. American Journal of Public Health; 104 (4): 603-611.

Bandyopadhyay S and Horowitz J (2006) Do plants overcomply with water pollution regulations? The role of discharge variability. Topics in Economic Analysis \& Policy; 6 (1)(online). doi:10.2202/1538-0653.1486.

Barry F (1970) The evolution of the enforcement provisions of the federal water pollution control act: A study of the difficulty in developing effective legislation. Michigan Law Review; 68 (6): 1103-1130.

Beirne P and South N (eds) (2007) Issues in green criminology. Routledge: London. Bellanca MA and Bailey DS (1977) Effects of chlorinated effluents on aquatic ecosystem in the lower James River. Water Pollution Control Federation Journal; 49 (4): 639-645.

Bennett EM, Carpenter CR and Caraco NF (2001) Human impact on erodable phosphorus and eutrophication: A global perspective; Increasing accumulation of phosphorus in soil threatens rivers, lakes, and coastal oceans with eutrophication. AIBS Bulletin; 51 (3): 227-234.

Bilotta GS and Brazier RE (2008) Understanding the influence of suspended solids on water quality and aquatic biota. Water Research; 42 (12): 2849-2861.

Borsuk ME, Stow CA and Reckhow KH (2002) Predicting the frequency of water quality standard violations: A probabilistic approach for TMDL development. Environmental Science \& Technology; 36 (10): 2109-2115.

Bradshaw EA (2015) Blockadia rising: Rowdy greens, direct action and the Keystone XL Pipeline. Critical Criminology; 32 (4): 433-448. 
Braithwaite V and Levi M (eds) (1998) Trust \& Governance. Russell Sage Foundation: New York, NY.

Brisman A (2008) Crime-environment relationships and environmental justice. Seattle Journal of. Social Justice; 6 (spring/summer): 727-907.

Brisman A and South N (2013) A green-cultural criminology: An exploratory outline. Crime, Media, Culture; 9 (2): 115-135.

Brix KV, DeForest DK and Adams WJ (2001) Assessing acute and chronic copper risks to freshwater aquatic life using species sensitivity distributions for different taxonomic groups. Environmental Toxicology and Chemistry; 20 (8): 1846-1856

Brungs WA (1973) Effects of residual chlorine on aquatic life. Water Pollution Control Federation Journal; 45 (10): 2180-2193.

Carpenter SR, Caraco NF, Correll DL, Howarth RW, Sharpley AN and Smith VH (1998) Nonpoint pollution of surface waters with phosphorus and nitrogen. Ecological Applications; 8 (3): 559-568.

Cerreno ALC, Panero M and Boehme S (2002) Pollution Prevention and Management Strategies for Mercury in the New York/New Jersey Harbor. New York Academy of Sciences: New York, NY.

Chambliss WJ, Michalowski RJ and Kramer RC (2010) State Crime in the Global Age. Willan: London.

Clearwater SJ, Thompson KJ and Hickey CW (2014) Acute toxicity of copper, zinc, and ammonia to larvae (Glochidia) of a native freshwater mussel Echyridella menziesii in New Zealand. Archives of Environmental Contamination and Toxicology; 66 (2): 213-226.

Coffey B and Marston G (2013) How neoliberalism and ecological modernization shaped environmental policy in Australia. Journal of Environmental Policy \& Planning; 15 (2): 179-199.

Correll DL (1998) The role of phosphorus in the eutrophication of receiving waters: A review. Journal of Environmental Quality; 27 (2): 261-266.

Daigger GT, Datta T, Stensel HD, Whitlock DD and Mackey JK (2014) Evaluating the role of point source discharges informs statewide nutrient control policy in Utah. Water Environment Research; 86 (6): 559-572.

Driscoll CT et al (2003) Nitrogen pollution in the northeastern United States: Sources, effects, and management options. BioScience; 53 (4): 357-374.

Earnhart D (2004) Regulatory factors shaping environmental performance at publicly-owned treatment plants. Journal of Environmental Economics and Management; 48 (1): 655-681.

Flippin TH, Petersen L, Brazil B and Radhakrishnan K (2014) Fats, oils and grease (FOG) pretreatment limits: Intent and serious impact of highly variable implementation. Proceedings of the Water Environment Federation; 13 (13): 6784-6789.

Gaba JM (2007) Generally illegal: NPDES general permits under the clean water act. Harvard Environmental Law Review; 31 (409): 410-473.

Ganoulis J (2009) Risk Analysis of Water Pollution. Wiley-VCH: Germany.

Helz GR and Nweke AC (1995) Incompleteness of wastewater dechlorination. Environmental Science \& Technology; 29 (4): 1018-1022.

Johnson H, South N and Walters R (2015) The commodification and exploitation of fresh water: Property, human rights and green criminology. International Journal of Law, Crime and Justice; 44 (5): 146-162.

Kemp P, Sear D, Collins A, Naden P and Jones I (2011) The impacts of fine sediment on riverine fish. Hydrological Processes; 25 (11): 1800-1821.

Lee A, Morton R and Tang C (2012) Controlling volatile organic compound emissions using biological techniques at the joint water pollution control plant. Proceedings of the Water Environment Federation; 2012 (9): 694-702.

Lo AY (2014) Negative income effect on perception of long-term environmental risk. Ecological Economics; 107 (November): 51-58.

Long MA, Stretesky PB, Lynch MJ and Fenwick E (2012) Crime in the coal industry: Implications for green criminology and treadmill of production. Organization \& Environment; 25 (3): 328-346.

Lynch MJ (1990) The greening of criminology: A perspective for the 1990s. The Critical Criminologist; 2 (3): 3-4, 11-12.

Lynch MJ, Barrett KL, Stretesky PB and Long MA (2017) The neglect of empirical research in green criminology and its consequences. Critical Criminology. doi:10.1007/s10612-017-9359-6.

Lynch MJ, Burns RG and Stretesky PB (2010) Global warming as a state-corporate Crime: The politicalization of global warming during the Bush administration. Crime, Law and Social Change; 54 (3): 213-239.

Lynch MJ, Burns RG and Stretesky PB (2014) Environmental Law, Crime and Justice: An Introduction, 2nd edn, LFB Scholarly: El Paso, TX.

Lynch MJ, Long MA, Barrett KL and Stretesky PB (2013) Is it a crime to produce ecological disorganization? Why green criminology and political economy matter in the analysis of global ecological harms. British Journal of Criminology; 53 (6): 997-1016.

Lynch MJ and Stretesky PB (2003) The meaning of green contrasting criminological perspectives. Theoretical Criminology; 7 (2): 217-238.

Lynch MJ and Stretesky PB (2013) The distribution of water-monitoring organizations across states: Implications for community policing. Policing: An International Journal of Police Strategies and Management; 36 (1): 6-26.
Lynch MJ and Stretesky PB (2014) Exploring Green Criminology: Toward a Green Revolution in C Criminology. Ashgate: Farnham, Surrey, UK.

Lynch MJ, Stretesky PB and Burns RG (2004) Determinants of environmental law violation fines against oil refineries: Race, ethnicity, income and aggregation effects. Society and Natural Resources; 17 (4): 333-347.

Maruya KA et al (2014) An adaptive, comprehensive monitoring strategy for chemicals of emerging concern (CECs) in California's Aquatic Ecosystems. Integrated Environmental Assessment and Management; 10 (1): 69-77.

Maruya KA, Vidal-Dorsch DE, Bay SM, Kwon JW, Xia K and Armbrust KL (2012) Organic contaminants of emerging concern in sediments and flatfish collected near outfalls discharging treated wastewater effluent to the Southern California Bight. Environmental Toxicology and Chemistry; 31 (12): 2683-2688.

Mayes MA, Alexander HC, Hopkins DL and Latvaitis PB (1986) Acute and chronic toxicity of ammonia to freshwater fish: A site-specific study. Environmental Toxicology and Chemistry; 5 (5): 437-442.

McClanahan B (2014) Green and grey: Water justice, criminalization, and resistance. Critical Criminology; 22 (3): 403-418.

Michalowski RJ and Kramer RC (2006) State-Corporate Crime. Rutgers University Press: Newark, NJ.

Mills WB, Lew CS and Loh JY (1998) Predictions of potential human health and ecological risks from power plant discharges of total residual chlorine and chloroform into rivers. Environmental Science \& Technology; 32 (14): 2162-2171.

Moloney CJ and Chambliss WJ (2014) Slaughtering the bison, controlling Native Americans: A state crime and green criminological synthesis. Critical Criminology; 22 (3): 319-338.

Mullins CW and Kauzlarich D (2000) The ghost dance and Wounded Knee: A criminological examination. Social Pathology; 6 (4): 264-283.

Oljaca N, Keeler AG and Dorfman J (1998) Penalty functions for environmental violations: Evidence from water quality enforcement. Journal of Regulatory Economics; 14 (3): 255-264.

Rahman T, Kohli M, Megdal S, Aradhyula S and Moxley J (2010) Determinants of environmental noncompliance by public water systems. Contemporary Economic Policy; 28 (2): 264-274.

Rothe DL (2009) State Criminality: The Crime of All Crimes. Lexington Books: Lanham, MD.

Rothe DL and Mullins CW (2011) State Crime: Current Perspectives. Rutgers University Press: Newark, NJ.

Ruggiero V and South N (2013a) Green criminology and crimes of the economy: Theory, research and praxis. Critical Criminology; 21 (3): 359-373.

Ruggiero V and South N (2013b) Toxic state-corporate crimes, Neo-liberalism and green criminology: the hazards and legacies of the oil, chemical and mineral industries. International Journal for Crime, Justice and Social Democracy; 2 (2): $12-26$.

Schnaiberg A (1980) The Environment: From Surplus to Scarcity. Oxford University Press: New York, NY.

Sharma PD (2009) Ecology and Environment. Rastogi Publications: New Delhi.

Sigman H (2002) Letting states do the dirty work: State responsibility for federal environmental regulation. Working Papers, Department of Economics, Rutgers, The State University of New Jersey, No. 2002-28.

Sollund RA (ed) (2015) Green Harms and Crimes: Critical Criminology in a Changing World. Palgrave MacMillan: Hampshire, UK.

South N (1998) A green field for criminology? A proposal for a perspective. Theoretical Criminology; 2 (2): 211-233.

Stretesky PB, Long MA and Lynch MJ (2013) Does environmental enforcement slow the treadmill of production? The relationship between large monetary penalties, ecological disorganization and toxic releases within offending corporations. Journal of Crime and Justice; 36 (2): 235-249.

Stretesky PB and Lynch MJ (1999) Environmental justice and the prediction of distance to accidental chemical releases in Hillsborough County, Florida. Social Science Quarterly; 80 (4): 830-846.

Stretesky PB and Lynch MJ (2002) Environmental hazards and school segregation in Hillsborough County, Florida, 1987-1999. The Sociological Quarterly; 43 (4): $553-573$.

Stretesky PB and Lynch MJ (2011) Coal strip mining, mountain top removal and the distribution of environmental violations across the United States, 2002 2008. Landscape Research; 36 (2): 209-230.

Tim US, Mostaghimi S and Shanholtz VO (1992) Identification of critical nonpoint pollution Source area using geographic information systems and water quality monitoring. Journal of the American Water Resources Association; 28 (5): 877-887.

Toffel MW and Marshall JD (2004) Improving environmental performance assessment: a comparative analysis of weighting methods used to evaluate chemical release inventories. Journal of Industrial Ecology; 8 (1-2): $143-172$.

US EPA. (2013) Aquatic Life Ambient Water Quality Criteria for Ammonia Freshwater. (EPA 822- R-13-001) US EPA: Washington, DC. 
Upadhyay N, Sun Q, Allen JO, Westerhoff P and Herckes P (2011) Synthetic musk emissions from wastewater aeration basins. Water Research; 45 (3): 1071-1078.

Vidal-Dorsch DE et al (2013a) Genomic and phenotypic response of hornyhead turbot exposed to municipal wastewater effluents. Aquatic Toxicology; 140 (12): 174-184.

Vidal-Dorsch DE et al (2013b) Gene expression of fathead minnows (Pimephales promelas) exposed to two types of treated municipal wastewater effluents. Environmental Science \& Technology; 47 (19): 11268-11277.

Vidal-Dorsch DE, Bay SM, Maruya K, Snyder SA, Trenholm RA and Vanderford BJ (2012) Contaminants of emerging concern in municipal wastewater effluents and marine receiving water. Environmental Toxicology and Chemistry; 31 (12): 2674-2682.

Weber-Scannell PK and Duffy LK (2007) Effects of total dissolved solids on aquatic organism: a review of literature and recommendation for salmonid species. American Journal of Environmental Sciences; 3 (1): 1-6.

Walters R (2006) Crime, bio-agriculture and the exploitation of hunger. British Journal of Criminology; 46 (1): 26-45.

Walters R (2007) Food crime, regulation and the biotech harvest. European Journal of Criminology; 4 (2): 217-235.

Walters R (2010) Toxic atmospheres: Air pollution, trade and the politics of regulation. Critical Criminology; 18 (4): 307-323.

White R (2007) Green criminology and the pursuit of social and ecological justice. In: Beirne P and South N (eds). Issues in Green Criminology: Confronting Harms Against Environments, humanity and Other Animals. Willan: Oxon, UK, pp 32-54.

White R (ed) (2009) Environmental crime: A reader. Willan: Portland, OR.

White R (ed) (2012) Climate Change from a Criminological Perspective. Springer: New York, NY.

White R (2013) Crimes Against Nature: Environmental Criminology and Ecological Justice. Willan: Oxon, UK.

White R and Kramer RC (2015) Critical criminology and the struggle against climate change ecocide. Critical Criminology; 23 (4): 383-399.
Wilson S, Hutson M and Mujahid M (2008) How planning and zoning contribute to inequitable development, neighborhood health, and environmental injustice. Environmental Justice; 1 (4): 211-216.

\section{Data availability}

All data analysed is included in the paper.

\section{Additional information}

Supplementary Information: accompanies this paper at http://www.palgrave-journals .com/palcomms

Competing interests: The authors declare that there are no competing interests.

Reprints and permission information is available at http://www.palgrave-journals.com/ pal/authors/rights_and_permissions.html

How to cite this article: Lynch MJ, Stretesky PB and Long MA (2017) State and green crimes related to water pollution and ecological disorganization: water pollution from publicly owned treatment works (POTW) facilities across US states. Palgrave Communications. 3:17070 doi: 10.1057/palcomms.2017.70.

Publisher's note: Springer Nature remains neutral with regard to jurisdictional claims in published maps and institutional affiliations.

\section{(c) (1)}

This work is licensed under a Creative Commons Attribution 4.0 International License. The images or other third party material in this article are included in the article's Creative Commons license, unless indicated otherwise in the credit line; if the material is not included under the Creative Commons license, users will need to obtain permission from the license holder to reproduce the material. To view a copy of this license, visit http://creativecommons.org/licenses/by/4.0/

(C) The Author(s) 2017 